\title{
APLIKASI SISTEM INFORMASI LOWONGAN PEKERJAAN BERBASIS ANDROID DAN WEB MONITORING (Penelitian dilakukan di Kab. Karawang)
}

\author{
${ }^{1}$ Baenil Huda \\ ${ }^{2}$ Saepul Apriyanto \\ Sistem Informasi, Fakultas Teknologi dan Ilmu Komputer, UBP Karawang \\ Jl. HS.Ronggo Waluyo, RT.014/RW.009, Puseurjaya, Telukjambe Timur, \\ Kabupaten Karawang, Jawa Barat 41361 \\ 1baeni188@ubpkarawang.ac.id \\ 2saepulaprianto@ubpkarawang.ac.id
}

\begin{abstract}
ABSTRAK
Tujuan penelitian adalah untuk (a) memberikan informasi lowongan pekerjaan secara real time. (b) mengetahui informasi lowongan pekerjaan secara cepat dan akurat. (c) mengirimkan cv pelamar dengan efektif dan efesien. Dalam penelitian ini, metode pengumpulan data yaitu dengan metode studi kasus dan metode pengembangan sistem yaitu dengan model waterfall. Kemudian dilengkapi perangkat Android yang akan digunakan dalam penginputan data informasi lowongan pekerjaan ataupun data informasi pelamar dan Web Monitoring sebagai penyedia informasi data terpusat yang ada di dinas sosial tenaga kerja. Dari hasil penelitian ini diharapkan mendapat informasi lowongan pekerjaan dan data pelamar yang valid sesuai dengan informasi sebenarnya. Serta tidak adanya penyalah gunaan dan manifulasi data. Khususnya informasi dari lowongan pekerjaan yang ada di kabupaten karawang.
\end{abstract}

Kata Kunci : Lowongan pekerjaan, real time, perangkat Android, Web Monitoring.

\section{Pendahuluan}

\subsection{Latar Belakang}

Masalah lowongan pekerjaan merupakan masalah serius yang bukan saja dihadapi oleh semua lapisan masyarakat di berbagai negara yang sedang berkembang maupun negara yang sudah maju. Karena banyak menyangkut segi kehidupan. Dalam perencanaan pembangunan disuatu negara perlu dituangkan dalam upaya meningkatkan kesejahteraan rakyat baik di daerah perkotaan maupun di daerah pedesaan.

Dalam mencari dan mendapatkan informasi lowongan pekerjaan yang cepat dan tepat, masyarakat dituntut untuk bisa mengakses informasi tersebut. Dan diperlukan suatu sistem yang mendukung proses dalam mencari informasi lowongan pekerjaan. 
Oleh karena persoalan tersebut diatas yang didasari latar belakang yang juga sudah dijelaskan, Penelitian ini akan mencoba membangun sebuah aplikasi mobile yang menyediakan berbagai informasi real time menggunakan perangkat Android untuk mempermudah dalam menginput data dan mengakses informasi yang sudah di sediakan oleh suatu web sebagai monitoring yang menyediakan informasi tersebut.

\subsection{Perumusan Masalah}

Dari uraian diatas, dengan maksud agar pembahasan dan penyusunannya dapat dilakukan secara terarah dan tercapai sesuai dengan yang diharapkan dan menghindari kesimpangsiuran, maka penelitian ini membatasi masalah pada Aplikasi Sistem Informasi Lowongan 
Pekerjaan Berbasis Android Dan Web Monitoring Kabupaten Karawang.

\section{Tinjauan Pustaka}

\subsection{Pengertian Sistem Informasi}

Menurut HengkyW.Pramana Aplikasi merupakan suatu unit perangkat lunak yang dibuat untuk melayani kebutuhan akan beberapa aktivitas seperti sistem perniagaan, game palayanan masyarakat, periklanan, atau semua proses yang hampir dilakukan manusia.

Menurut Jogiyanto aplikasi merupakan penggunaan dalam suatu komputer, instruksi (instruction) atau pernyataan (statement) yang disusun sedemikian rupa sehingga komputer dapat memproses input menjadi output.

\subsection{Pengertian Penduduk}

Menurut Schrode dan Voich (Schrode, 1994), Sistem adalah "whole compounded of several parts" (suatu kesatuan yang

tersusun dari sejumlah elemen). Sedangkan menurut Elias M. Awad (Elias, 1979) bahwa sistem adalah "an organized functioning relationship among units or components" (hubungan fungsional yang terorganisasi/teratur, yang berlangsung di antara bagianbagian atau elemen-elemen).

Jadi menurut Hartono B (Hartono,

2013:9). bahwa sistem adalah suatu himpunan dari berbagai bagian atau elemen, yang saling berhubungan secara

terorganisasi berdasarkan fungsi-fungsinya, menjadi suatu kesatuan.

Informasi pada dasarnya adalah sehimpunan data yang telah diolah menjadi sesuatu yang memiliki arti dan kegunaan lebih luas. Lippeveld, Sauerbon, dan Bodart (2000) mendefinisikan

informasi sebagai "a meaningful collection of facts or data" (sehimpunan fakta atau data yang memiliki makna). Sedangkan Gordon B.Davis (1994) memberikan definisi informasi sebagai berikut.

Information is data that has been processed into a form that is meaningful 
to the recipient and is of real or perceived value in current or prospective decision. (informasi adalah data yang telah diolah menjadi suatu bentuk yang berguna bagi penerimanya dan memiliki nilai bagi pengambilan keputusan saat ini atau di masa yang akan datang). (Hartono B., 2013:15).

Jadi, sistem informasi ialah suatu himpunan dari elemen-elemen data, yang saling berhubungan secara terorganisasi berdasarkan fungsi-fungsinya, menjadi suatu kesatuan yang berguna bagi penerimanya dan memiliki nilai bagi pengambilan keputusan saat ini atau di masa yang akan datang.

\subsection{Pengertian Android}

Android adalah sistem operasi berbasis Linux yang dimodifikasi untuk perangkat bergerak (mobile device) yang terdiri dari sistem operasi, middleware, dan aplikasi-

aplikasi utama. Awalnya, Andorid dikembangkan oleh Android inc. perusahaan ini kemudian dibeli oleh Google pada tahun 2005. Sistem operasi Android kemudian diluncurkan bersamaan dengan dibentuknya organisasi Operasi Handset Alliance tahun 2007. Selain Google, beberapa nama-nama besar juga ikut serta dalam Open Handset Alliance, Antara lain Motorola, Samsung, LG, Ericsson, T-Mobile, Vodafone, Tpshiba, dan Intel.

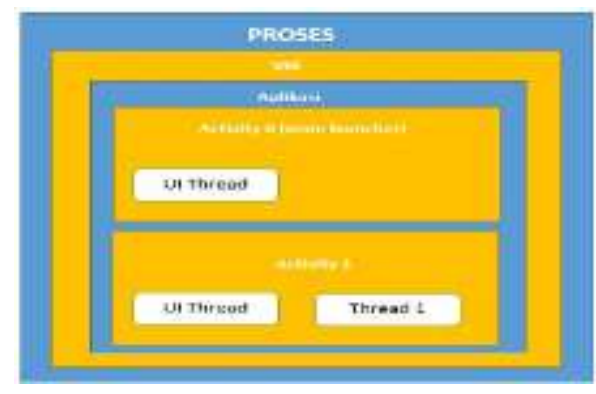

Gambar : Model Aplikasi Android

\subsection{Pengertian Web}

Website adalah kumpulan halaman web yang saling terhubung dan file-filenya saling terkait. Web terdiri dari page atau halaman, dan kumpulan halaman yang dinamakan homepage. Homepage berada pada posisi teratas, 
dengan halaman-halaman terkait berada di bawahnya. Biasanya setiap halaman di bawah homepage disebut child page, yang berisi hyperlink ke halaman lain dalam web (Gregorius, 2000:30).

\section{Tujuan dan Manfaat Penelitian 3.1.Tujuan Penelitian}

- memberikan informasi lowongan pekerjaan secara real time.

- mengetahui informasi lowongan pekerjaan secara cepat dan akurat.

- mengirimkan cv pelamar dengan efektif dan efesien

\subsection{Manfaat Penelitian}

Dalam penelitian ini diharapkan dapat bermanfaat diantaranya adalah:

a. Untuk mengetahui kebutuhan lapangan pekerjaan yang tersebar diberbagai bidang usaha.

b. Untuk mengetahui data dari pelamar kerja baik yang diterima maupun yang ditolak oleh perusahaan.

\section{Metodologi Penelitian}

Metodologi penelitian ini disusun berdasarkan hasil dari analisis terhadap model penelitian yang akan digunakan, hasil dari pada pemilihan pengembangan sistem maka digunakan model Waterfall, berikut merupakan flowgraf metodologi penelitian ini:

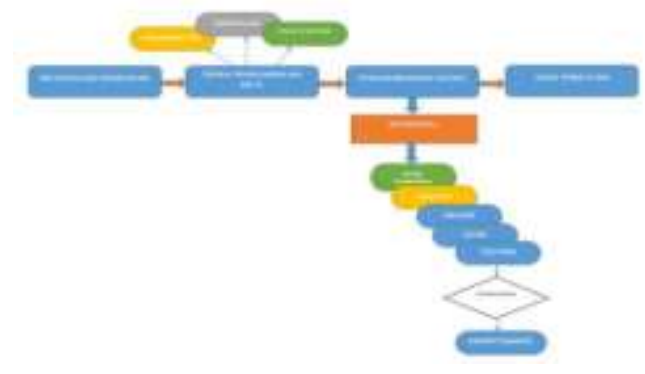

Gambar 3.1 Diagram Alur Penelitian

4.1.Metode Pengumpulan Data Penelitian ini menggunakan pendekatan kualitatif dengan metode yang digunakan yaitu metode studi kasus. Gempur Santoso (2005:30) mengatakan bahwa studi kasus adalah penelitian yang pada umumnya bertujuan untuk mempelajari secara 
mendalam terhadap suatu individu, kelompok, lembaga, atau masyarakat tertentu. Tentang latar belakang, keadaan sekarang, atau interaksi yang terjadi.

Deskriptif Kualitatif (Nana Sudjana : 203) adalah penelitian yang data-datanya berupa katakata (bukan angka-angka, yang berasal dari wawancara, catatan laporan, dokumen dll) atau penelitian yang di dalamnya mengutamakan untuk pendiskripsian secara analisis sesuatu peristiwa atau proses sebagaimana adanya dalam lingkungan yang alami untuk memperoleh makna yang mendalam dari hakekat proses tersebut

Dalam penelitian ini penulis menggunakan tiga macam teknik pengumpulan data, yaitu: Observasi, Wawancara, dan Dokumentasi.

\subsection{Metode Pengembangan Sistem Informasi}

Metode pengembangan sistem yang digunakan untuk membangun sistem ini adalah

Model Waterfall. Waterfall adalah suatu metode pengembangan perangkat lunak yang mengusulkan pendekatan kepada perangkat lunak sistematik dan sekuensial yang mulai pada tingkat kemajuan system pada seluruh analisis, design, kode, pengujian dan pemeliharaan. Alasan peneliti menggunakan metode waterfall karena pengaplikasian menggunakan model ini mudah, kelebihan dari model ini juga ketika semua kebutuhan sistem dapat didefinisikan secara utuh, eksplisit dan benar di awal project, maka waterfall dapat berjalan dengan baik dan tanpa masalah. Walaupun tahap demi tahap yang dilalui harus menunggu selesainya tahap sebelumnya dan berjalan berurutan.

Beberapa tahap-tahap metode waterfall, yaitu: seperti gambar di bawah ini. 


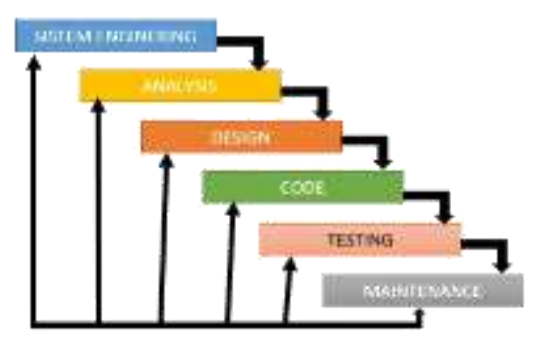

ISSN : 2541-6995

E ISSN : $2580-5517$

\section{Gambar : Metode Waterfall}

Secara detail penjelasan gambar, yaitu:

1. System Enginering, merupakan bagian awal dari pengerjaan suatu proyek perangkat lunak. Dimulai dengan mempersiapkan segala hal yang diperlukan dalam pelaksanaan proyek.

2. Analysis, merupakan tahapan dimana System Enginering menganalisa segala hal yang ada pada pembuatan proyek atau pengembangan perangkat lunak yang bertujuan untuk memahami sistem yang ada, mengidentifikasi maslah dan mencari solusinya.

3. Design, merupakan tahapan penerjemah dari keperluan atau data yang telah dianalisis ke dalam bentuk yang mudah dimengerti oleh pemakai (user).

4. Coding, merupakan tahapan penerjemah data yang dirancang ke dalam Bahasa pemograman yang telah ditentukan.

5. Testing, merupakan tahapan uji coba terhadap sistem atau program setelah selesai dibuat.

6. Maintenance, merupakan tahapan penerapan sistem secara keseluruhan disertai pemeliharaan jika terjadi perubahan struktur, baik dari segi software maupun hardware.

\section{Hasil dan Luaran}

\subsection{Hasil Wawancara}

Berdasarakan data hasil wawancara diatas dapat disimpulkan bahwa identifikasi masalah yang ditemui Antara lain:

1. Para pelamar kerja diharuskan datang ke disnaker dimana info lowongan pekerjaan ditempel di papan pengumuman dan mading.

2. Pada saat pengumuman harus juga datang langsung ke disnaker untuk melihat hasilnya diterima atau tidak 
3. Harus menyiapkan berkas lamaran kerja dan mengirimkannya melalui kantor pos atau jasa antar

4. Pembuatan jadwal interview yang tidak terotomasi sehingga harus memilah berkas pada saat interview pelamar kerja

5. Harus memilih media untuk mengiklankan kebutuhan pegawai dengan cepat dan tepat

\subsection{Hasil Perancangan Sistem}

\begin{tabular}{|c|c|c|}
\hline Aktor & Tipe Aktor & Aktifitas Aktor \\
\hline $\begin{array}{l}\text { HRD } \\
\text { Peruablaan }\end{array}$ & $\begin{array}{l}\text { Primary } \\
\text { Bumines } \\
\text { Actor }\end{array}$ & $\begin{array}{l}\text { Orang yeng berinterakss langusug dengan sistem } \\
\text { untuk menginpus data lowongan pekerjaan }\end{array}$ \\
\hline Adrain & $\begin{array}{l}\text { Primaty } \\
\text { System } \\
\text { Actor }\end{array}$ & 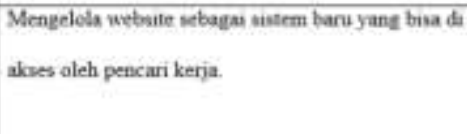 \\
\hline $\begin{array}{l}\text { Pescani } \\
\text { Kerja }\end{array}$ & $\begin{array}{l}\text { External } \\
\text { Rectiving } \\
\text { Actor }\end{array}$ & Menerima informasi lowongan peierjaan \\
\hline
\end{tabular}

B. Dugpam Activity

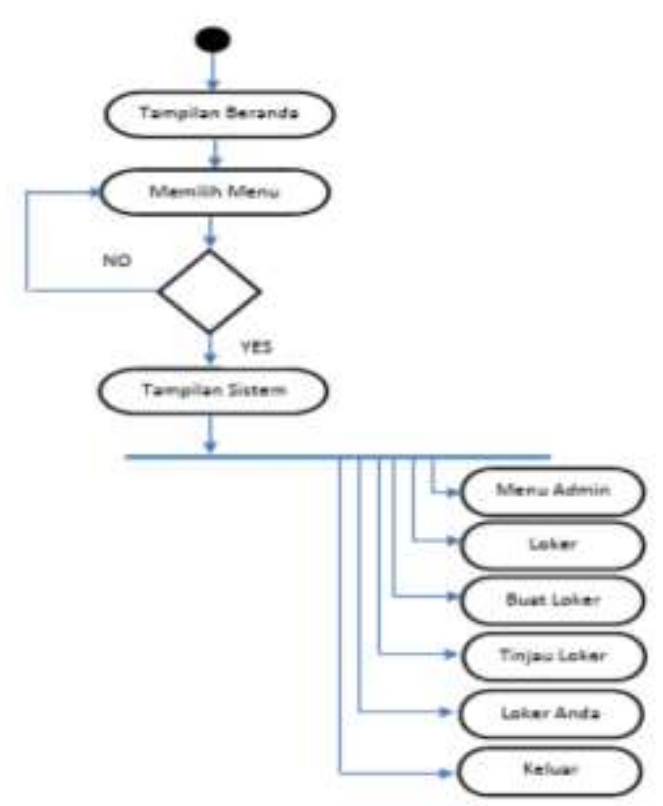

Gambat 4,16. Artivity Diagum Sistem Lotwongm Pekejasm 


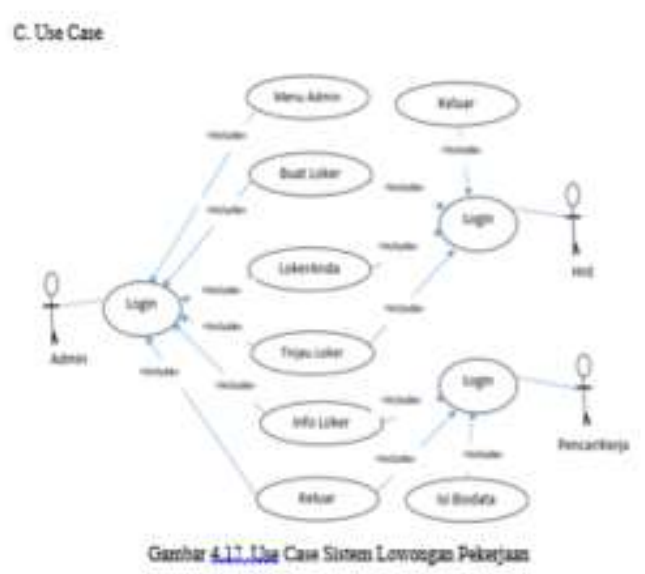

5.3 Hasil Perancangan Layer Antarmuka

\subsubsection{User Interface untuk Android}

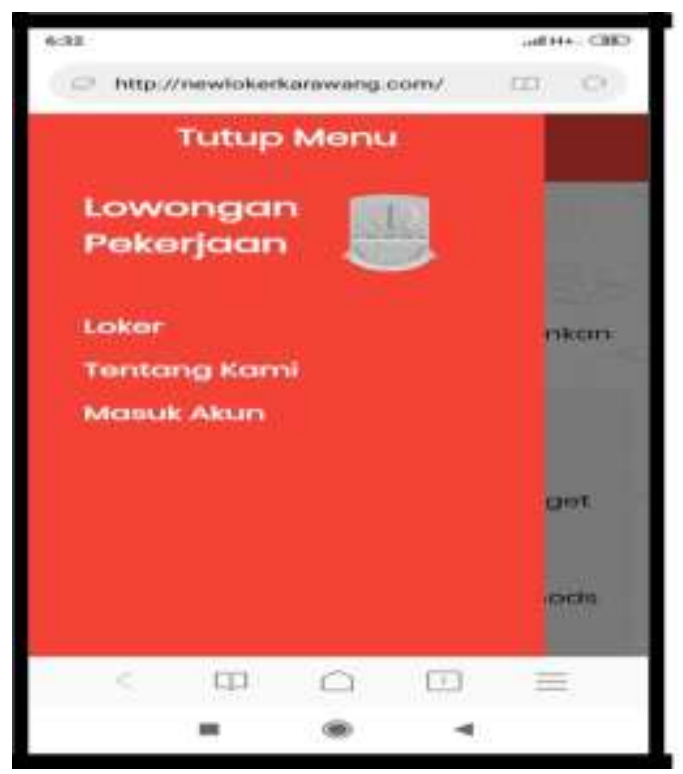

Gambar 4.19 menu pada android

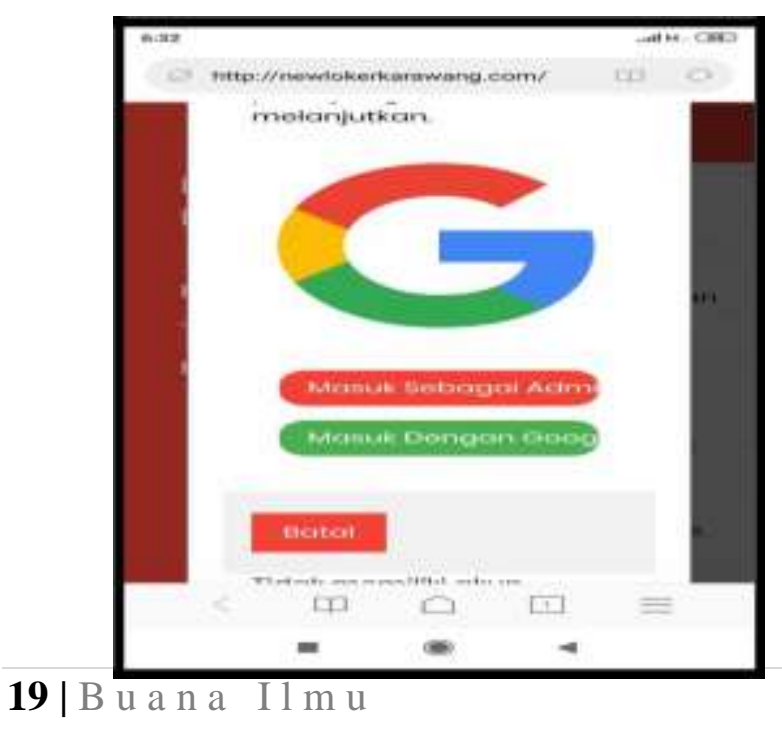

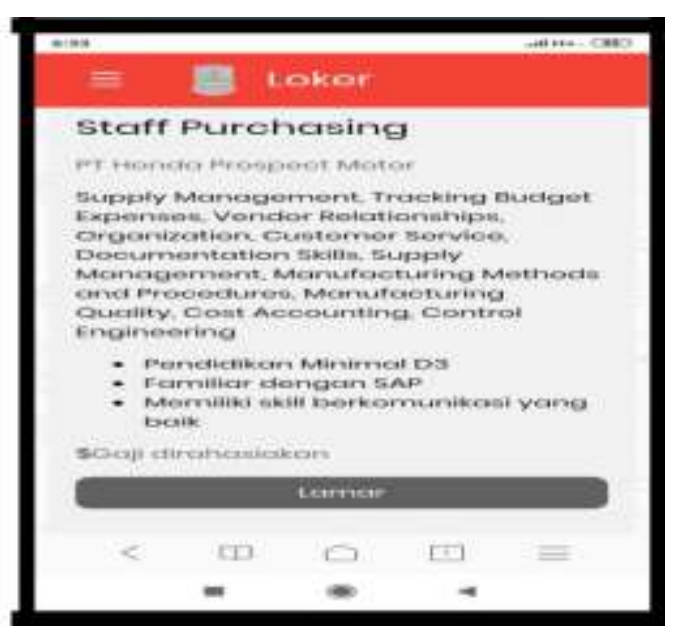

Gambar 4.21 menu loker pada android

\subsubsection{User Interface untuk Web}

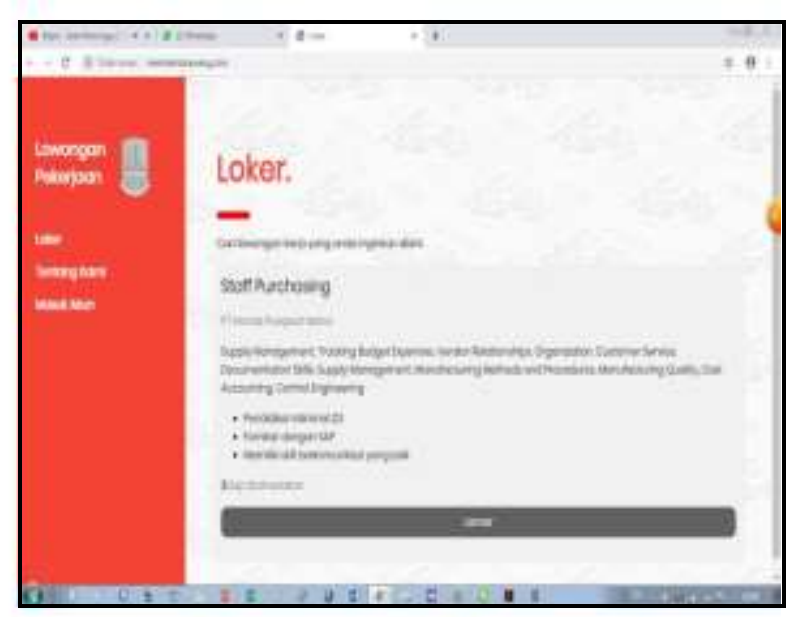


Baenil Huda, Saepul Apriyanto Vol 4 No 1

ISSN : 2541-6995

E ISSN : 2580-5517

Gambar 4.22 beranda

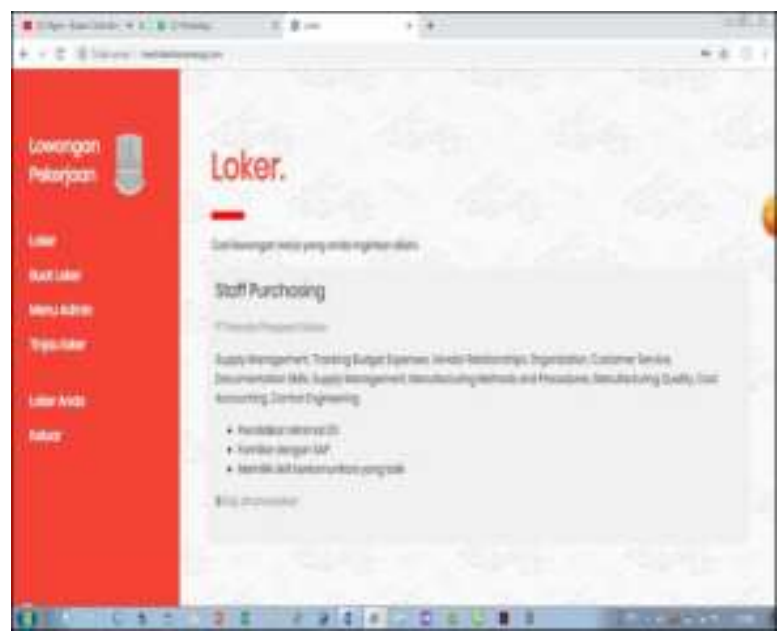

Gambar 4.20 menu login pada android 


\section{4}

Analisis Kebutuhan Sistem

4.4.1 Konfigurasi Hardware

a. Hardware pendukung Android

1. Komputer Prosesor i3

2. RAM 8 GB

3. Hardisk 500 GB

4. Hp Android Xiomi

b. Hardware pendukung Website

1. Komputer Prosesor i3

2. RAM 8 GB

3. Hardisk $500 \mathrm{~GB}$

4.4.2 Konfigurasi Software

a. kebutuhan software Android

1. Windows 10

2. Eclipse IDE

3. Android SDK

4. Emulator Android

b. kebutuhan software Website

1. Windows 10

2. Notepad++/Sublime Text 3

3. Codeigniter 3.1

4. Xampp

5. HeidiSQL

\section{Kesimpulan Dan Saran}

\subsection{Kesimpulan}

Kesimpulan yang diperoleh dari hasil penelitian pendahuluan yang dilakukan menunjukan bahwa dalam proses informasi lowongan pekerjaan harus menggunakan sistem berbasis website serta menggunakan perangkat pendukung yang berbasis Android guna kecepatan dan keakuratan data yang diproses.

\subsection{Saran}

Penerapan sistem informasi diharapkan dapat digunakan dengan baik sesuai dengan keperluan dalam proses pencarian lowongan pekerjaan di segala bidang organisasi yang ada di kabupaten karawang. 


\section{DAFTAR PUSTAKA}

[1]. Abdul K., From Zero to A Pro - Pemograman Aplikasi Android. CV.Andi Offset. Yogyakarta 2013.

[2] Budi R., Mudah Belajar PHP Teknik Penggunaan Fitur-Fitur Baru dalam PHP 5. Informatika Bandung 2015.

[3] Dr.Eng.Sianipar R.H., PHP \& MySQL Langkag Demi Langkah. CV.Andi Offset. Yogyakarta 2015.

[4] Zamrony P. J., Panduan Lengkap Pemograman Android. CV.Andi Offset. Yogyakarta 2016.

[5] Pressman, Roger S. (2001). Software Engineering A Practitioner's Approach Fifth Edition. New York: Mc Graw Hill Higer Education.

[6] Margono S. Drs. 2007. Metologi Penelitian Pendidikan Komponen MKDK. PT. Rineka Cipta, Jakarta

[7] SISTEM INFORMASI LOWONGAN KERJABERBASISWEB

Maryanah Safitri1, Aldhila Novianti2, Astrid Noviriandini3 1)Teknik Informatika Jurnal PILAR Nusa Mandiri Vol. 14, No. 1 Maret 2018 STMIK Nusa Mandiri Jakarta http://www.nusamandiri. ac. id maryanahsafitri@gmail.com

2)Manajemen Informatika P-ISSN: 1978-1946 | E-ISSN: 2527-6514 |

SistemInformasiLowongan...

AMIKBSITangerang

http://www.bsi.ac.id

aldhilanovianti1@gmail.com 3) Ilmu Komputer STMIK Nusa

Mandiri Jakarta http://www.nusamandiri.ac.id astridnovi81@gmail.com.

[8] JURNAL SAINS DAN INFORMATIKA Research of Science and Informatic V3.I2 (118125)Copyright@2017 by Kopertis Wilayah X 118 E-ISSN : 2502-096X P-ISSN :2459-

PERANCANGANAPLIKASI

MEDIAINFORMASI

LOWONGAN KERJA PERUSAHAAN BAGI PENCARI 
ISSN : 2541-6995

E ISSN : 2580-5517

KERJA BERBASIS WEB Efmi Maiyana Managemen Informatika, AMIK Boekittinggi, Jln By Pass Simpang Taluak, Bukttinggiefmi_maiyana@yahoo.co m Submitted: 24-11-2017, Reviewed: 28-11- 2017, Accepted 28-11-2017

http://doi.org/10.22216/jsi.v3i2.289 [9]Jurnal 3. Pengembangan Teknologi Informasi dan Ilmu Komputer eISSN: 2548-964X Vol. 2, No. 1, Januari 2018, hlm. 168-174 http://jptiik.ub.ac.id Fakultas Ilmu Komputer Universitas Brawijaya Pembangunan Aplikasi Penyedia Informasi Lowongan Pekerjaan Menggunakan Youtube API Pada Smartphone Android Ervin Winardo Toepak, Issa Arwani, Tri Afirianto Program Studi Teknik Informatika, Fakultas Ilmu Komputer, Universitas Brawijaya Email: ervinwinardo@gmail.com,issa.arwa ni@ub.ac.id,tri.afirianto@ub.ac.id.

[10] Jurnal Ilmiah Informatika Volume 2 No.

1 / Juni 2017 PERANCANGAN

LOWONGAN KERJA ONLINE BERBASIS WEB PADA PT ANH

Akhsani Taqwiym 1), Novan Wijaya 2) 1Komputerisasi Akuntansi, STMIK GI MDP email: akhsani.taqwiym@mdp.ac.id 2 Manajemen Informatika, AMIK MDP email: novan.wijaya@mdp.ac.id.

[11] Vol. 6 No. 1 April 2018 Jurnal TEKNOIF ISSN: 2338-2724 eISSN: 2598-9197 DOI 10.21063/JTIF.2018.V6.1.48-54 48 (C) 2018 ITP Press. All rights reserved. PERANCANGAN SISTEM INFORMASI PENCARIAN LOWONGAN PEKERJAAN Dede Wira Trise Putra1), Jendra Jonika Putra2) 1Dosen Teknik Informatika
Teknologi Padang Email: dedewtp339@yahoo.com

[12] Jurnal Cendikia Vol. XVI Cendikia 2018 P-ISSN:0216-9436 Bandar Lampung, Oktober 2018 EISSN:2622-6782

RANCANG
SISTEM
LOWONGAN
BERBASIS

BANGUN INFORMASI PEKERJAAN Susilawati1 1AMIK Dian Cipta Cendikia Bandar Lampung $\mathrm{Jl}$. Cut Nyak Dien No. 65 Palapa Durian Payung, Bandar Lampung Telp (0721) 783788 EMail :beti@dcc.ac.id

[13] Jurnal Sistem Informasi, Vol. 8 No. 2, September 2013: 139 - 148 Sistem Informasi Lowongan dan Lamaran Pekerjaan Berbasis Web Menggunakan ASP.NET Swarry Chalatra Prameswara, Meliana Christianti J. Jurusan S1 Teknik Informatika Fakultas Teknologi Informasi, Universitas Kristen Maranatha J1. Prof. Drg. Suria Sumantri No. 65 Bandung 40164 email: swarry.chalatra@gmail.com, meliana.christianti@it.maranatha.edu 
Baenil Huda, Saepul Apriyanto Vol 4 No 1

ISSN : 2541-6995

E ISSN : 2580-5517

2Mahasiswa Teknik Informatika

Fakultas Teknologi industri, Institut 